\title{
Use of Engineering Geophysics to Investigate Gbongon Flyover Bridge Foundation, Gbongon, Southwest Nigeria
}

\section{I.E Ogundipe ${ }^{1}$ \\ A.K Ogundana ${ }^{2}$ O.O Afolabi ${ }^{3}$}

${ }^{1,2, s}$ Department of Geology, Afe Babalola University, Ado Ekiti, Nigeria Emaili ibukuno8ogundipe@gmail.com Tel:08033770591

sEmail:dejiogundana@gmail.com Tel:08149945350

'Email:bukky.doly@yahoo.com Tel:08026525117

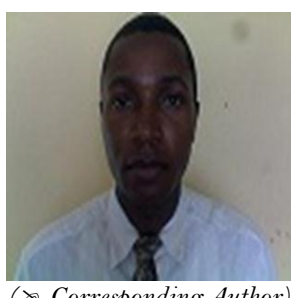

( Corresponding Author)

\begin{abstract}
Engineering geophysical investigation was conducted to understudy the structural and lithological characteristics of subsurface materials with the aim of determining the appropriate location, competent layer and depth of core holes required for geotechnical analysis at a proposed site for a flyover bridge at Gbongon using electrical resistivity method (Sounding and Profiling). The different subsurface lithologies were delineated and depth to the top of the different layers was determined. Approximate thickness of the different subsurface layers and depth to the top of the basement or competent layers were established. The lateral or horizontal continuity of the subsurface layers was also delineated. Three different subsurface lithologic units were established from the sounding curves namely; lateritic topsoil, clayey-sand and, fresh basement. The topsoil is relatively thin along the traverse with average resistivity and thickness values of $45 \Omega \mathrm{m}$ and $4.0 \mathrm{~m}$ respectively, and is predominantly lateritic clay. Clayey-sand was encountered at shallow depths of 4.0meters on the average in all locations and the average resistivity and thickness values for the Clayey-sand are, $56 \Omega \mathrm{m}$, and $5.0 \mathrm{~m}$ respectively. Basement is the fresh bedrock and is the last layer. It is relatively shallow in the study area and the average resistivity and depth values to the top of basement are, $1302 \Omega \mathrm{m}$, and $9.0 \mathrm{~m}$ respectively. The resistivity values are high because of its crystalline nature. The overburden is assumed to include all materials above the presumably fresh basement which is regarded as the competent layer in this case. The depth to the bedrock varies from 7.0 to $10.0 \mathrm{~m}$ and the average depth to the bedrock is $9.0 \mathrm{~m}$.
\end{abstract}

Keywords: Basement, Resistivity, Lithology, Overburden, Topsoil, Subsurface.

Citation I.E Ogundipe; A.K Ogundana; O.O Afolabi (2018). Use of Engineering Geophysics to Investigate Gbongon Flyover Bridge Foundation, Gbongon, Southwest Nigeria. World Scientific Research, 5(1): 57-61.

History:

Received: 2 August 2018

Revised: 7 September 2018

Accepted: 11 October 2018

Published: 15 November 2018

Licensed: This work is licensed under a Creative Commons

Attribution 3.0 License (oc)

Publisher: Asian Online Journal Publishing Group
Contribution/Acknowledgement: All authors contributed to the conception and design of the study.

Funding: This study received no specific financial support

Competing Interests: The authors declare that they have no conflict of interests.

Transparency: The authors confirm that the manuscript is an honest, accurate, and transparent account of the study was reported; that no vital features of the study have been omitted; and that any discrepancies from the study as planned have been explained.

Ethical: This study follows all ethical practices during writing.

\section{Contents}

1. Introduction .................58 58

2. Method

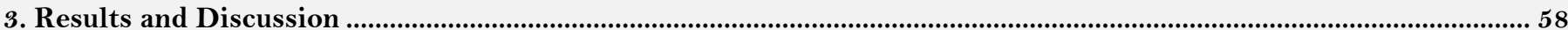

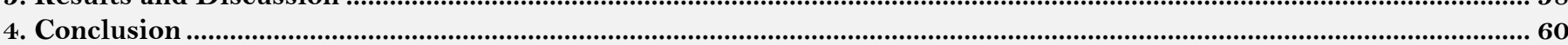

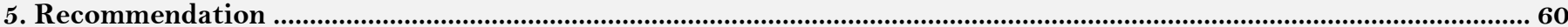

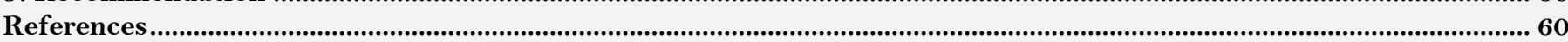




\section{Introduction}

A reconnaissance survey of Gbongon bridge site was carried out for site familiarization and planning. This was followed with a pre-coring geophysical investigation of the site and environs to allow for an informed approach to the proper coring programme.

The geophysical investigation was conducted to understudy the structural and lithological characteristics of the area. The different subsurface lithologies were delineated and depth to the top of the different subsurface layers were determined. Approximate thickness of the different subsurface layers and depth to the top of the basement or competent layers were established. The lateral or horizontal continuity of the subsurface layers were also delineated.

Electrical resistivity method has been used extensively in groundwater investigation especially in the basement complex terrains (Grant and West, 1965; Anhaeusser et al., 1969; Olorunfemi and Olorunniwo, 1985; Olorunfemi, 1990; Olorunfemi and Olayinka, 1992). The method is commonly used in getting detailed information about hydrogeological settings for groundwater, geologic mapping, foundation investigation and environmental studies. Some of these include aquifer delineation, subsurface mapping, lithological boundary differentiation and geothermal exploration.

The study aims at assessing depth to competent layer in this area with emphasis on the delineation of the fracture system, overburden thickness and lithological variation across the terrain.

\subsection{Location and Geology of the Study Area}

The study area is a juncture at Gbongon along Ilesha Ibadan highway. Gbongon is a town in Osun state, southwest Nigeria. Gbongon falls within the basement complex terrain of southwestern Nigeria and is underlain by crystalline rocks made of Older granite, Migmatite and Charnockites (Rahaman, 1989). The study area has little or no fracture in most location with accompanied shallow overburden.

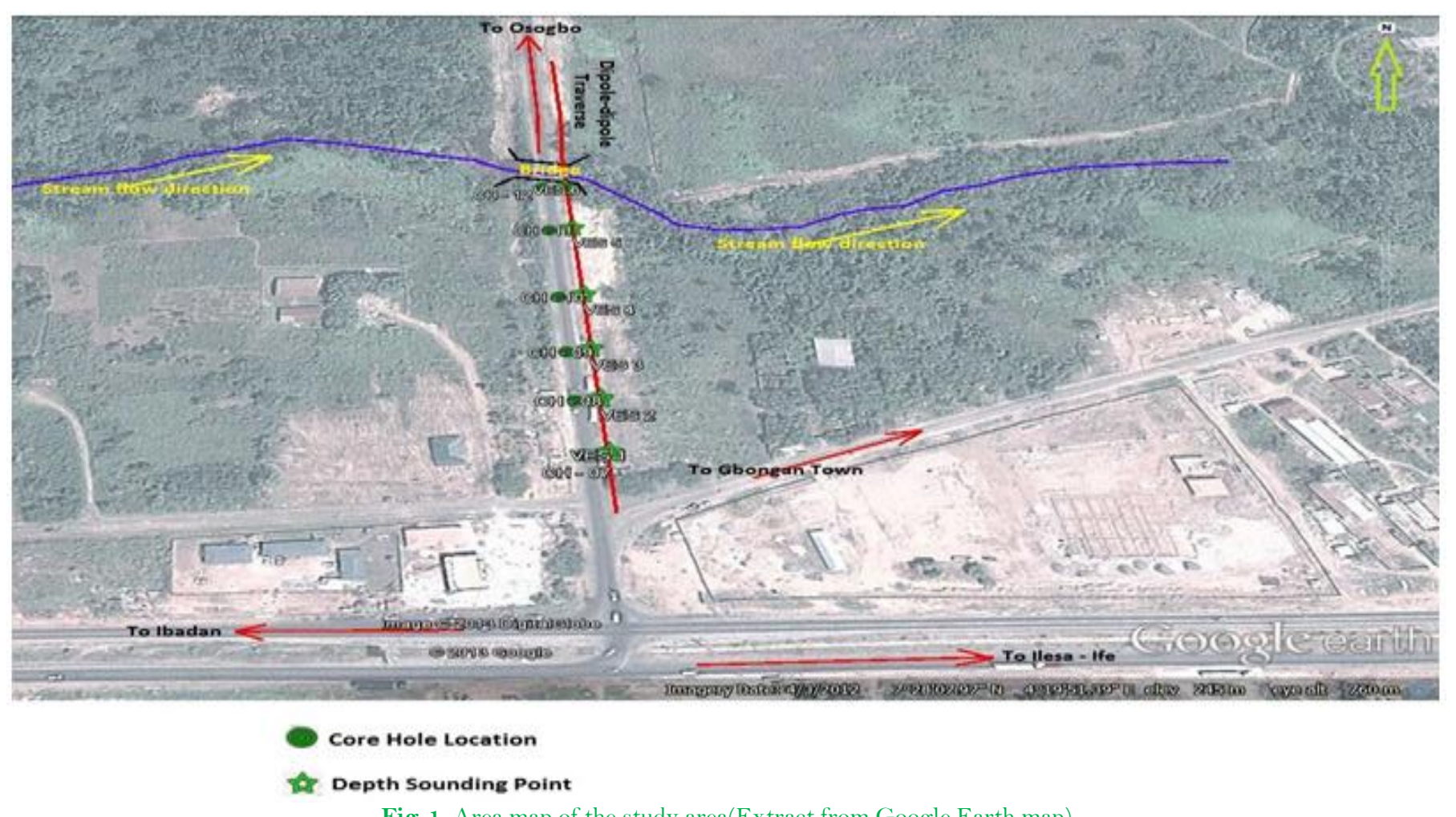

\section{Method}

Geophysical methods are indirect site investigation techniques and predominantly non-intrusive. It is relatively cheap, fast and environmental friendly. Vertical electrical sounding and resistivity profiling methods were adopted. The methods are highly reliable and reproducible. Soil resistivity meter was used for the geophysical tests.

Sounding revealed vertical resistivity variations while profiling helped in resolving horizontal resistivity variation in this study, thus establishing the vertical and lateral continuity of the various subsurface lithological units. Profiling method was employed using Schlumberger dipole- dipole configurations.

\section{Results and Discussion}

Three different subsurface lithological units were established from the sounding curves namely; lateritic topsoil, clayey-sand and, fresh basement.

The topsoil thickness is relatively thin along these traverses. The average resistivity and thickness values for the topsoil are $45 \Omega \mathrm{m}$ and $4.0 \mathrm{~m}$ respectively, which is predominantly lateritic clay.

Clayey-sand was encountered at shallow depths of 4.Ometers on the average in all locations and the average resistivity and thickness values for the Clayey-sand are, $56 \Omega \mathrm{m}$, and $5.0 \mathrm{~m}$ respectively.

The basement is the fresh bedrock and is the last layer. It is relatively shallow in the study area and the average resistivity and depth values to the top of basement are, $1302 \Omega \mathrm{m}$, and $9.0 \mathrm{~m}$ respectively. The resistivity values are high because of its crystalline nature.

The overburden is assumed to include all materials above the presumably fresh basement. The depth to the bedrock varies from 7.0 to $10.0 \mathrm{~m}$ and the average depth to the bedrock is $9.0 \mathrm{~m}$. 

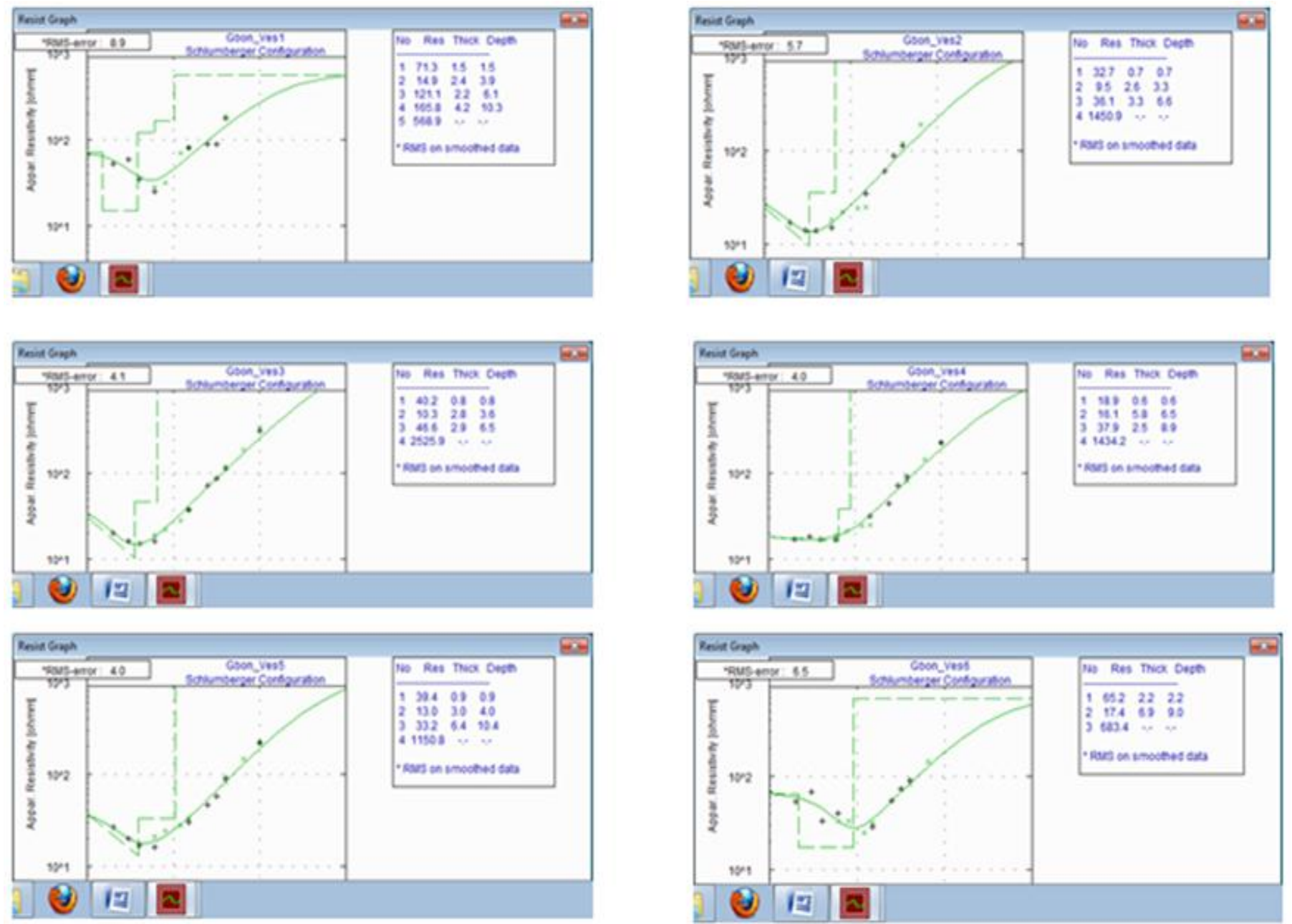

Fig-2. Geoelectric Curves of VES 1,2,3,4,5 \& 6 of the study area.

Note: it is the configuration plot from the field data using winresist software

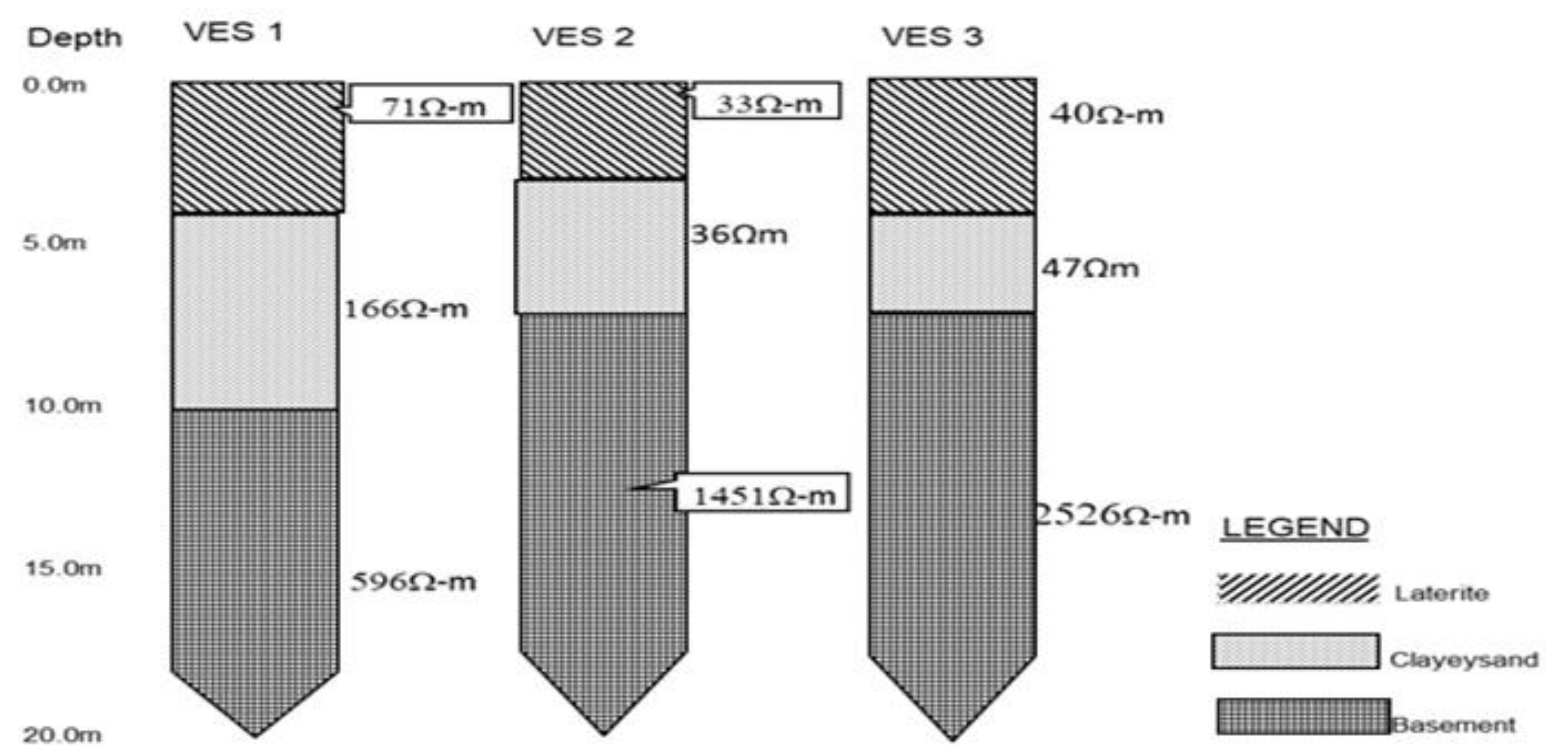

Fig-3a. Geoelectric Sections of VES 4, 5 \& 6 of the study area.note:generated from the data obtained from the field work.

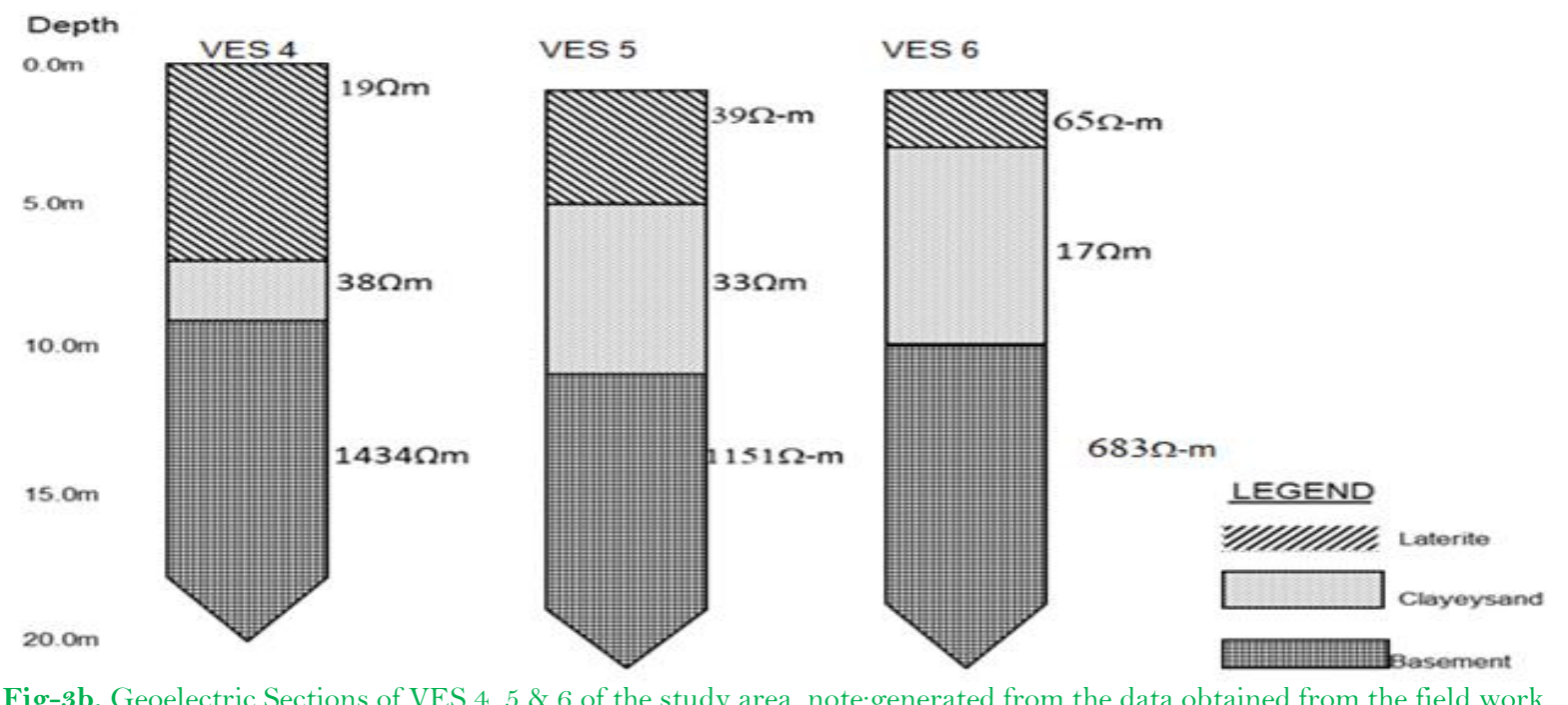


Result of the profiling traverse sections in N-S direction is presented in the section bellow. The traverse is 350 meters long and spreads across the six (6) proposed coreholes. Three continuous subsurface lithologic units namely; Lateritic topsoil (blue), Clayey-sand (greenish-yellowish-brown) and Fresh basement (reddish purple) were established across the entire profile section. The result is presented in form of 2-D resistivity structure bellow. The 2-D resistivity plot revealed a relatively thin overburden and shallow basement across the entire area. The overburden is thicker at the northern end and thins out toward the southern part.

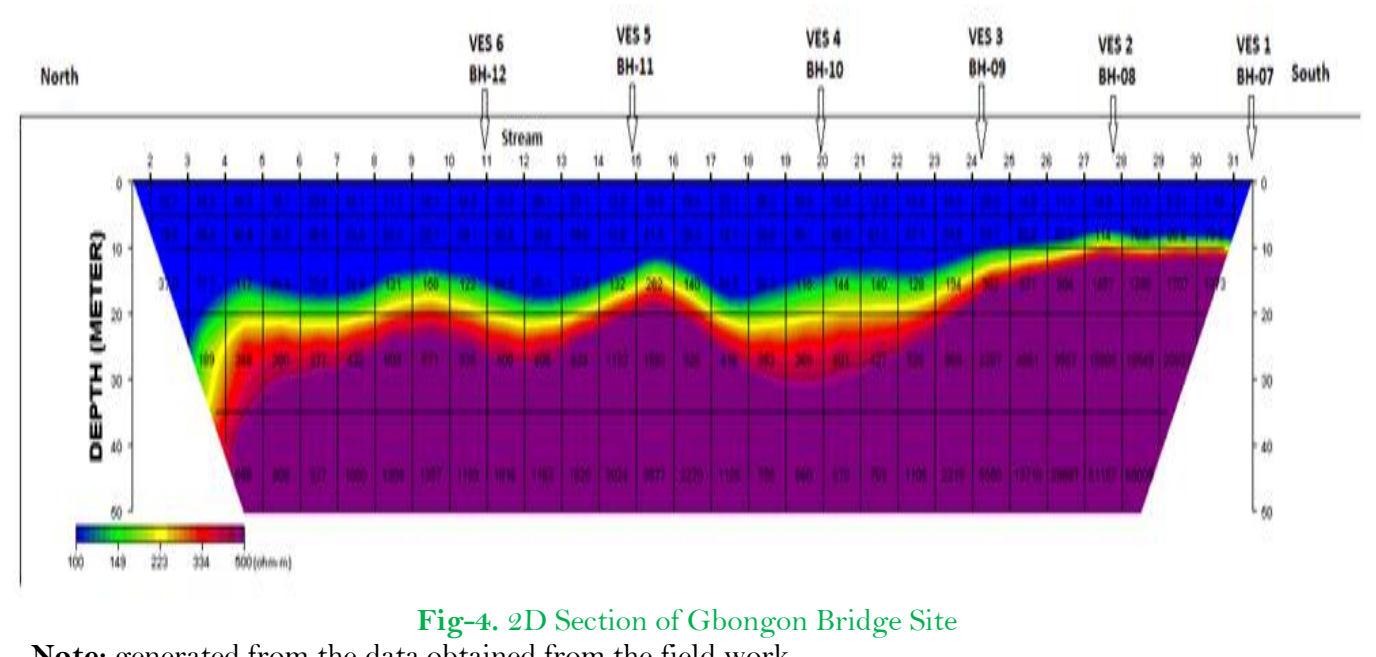

Note: generated from the data obtained from the field work.

\section{Conclusion}

Given the relatively thin overburden thickness and averagely shallow depth to the top of basement/competent layer across the study area, a corehole of twenty meter $(15.0 \mathrm{~m})$ will encounter basement/competent layer along the study traverse. Coreholes at the southern end of the traverse are expected to be shallower while those on the northern end are likely to be slightly deeper.

\section{Recommendation}

Standard penetration test (SPT) and Cone penetrometer test (CPT) could be added as insitu geothechnical approach to delineating depth to competent subsurface layers before the actual coring. The two methods are cheap, fast, and environmental friendly.

\section{References}

Anhaeusser, C.R., R. Mason, M.J. Viljoen and R.P. Viljoen, 1969. A reappraisal of some aspects of precambrian shield geology. Geological Society of America Bulletin, 80(1 1): 2175-2200. DOI https://doi.org/10.1 130/0016-7606(1969)80[2 175:arosao ]2.0.co;2

Grant, F.S. and G.F. West, 1965. Interpretation theory in applied geophysics. New York: McGraw-Hill.

Olorunfemi, M., 1990. The hydrogeological implication of topographic variation with overburden thickness in basement complex. Area of SW Nigeria. Journal and Mining and Geology, 26(1).

Olorunfemi, M. and A. Olayinka, 1992. Alteration of geoelectric in Okene are and Implication for Borehole sitting. Journal of Mining and Geology: 403-411.

Olorunfemi, M. and M. Olorunniwo, 1985. Geoelectric parameters and aquifer characteristics of some parts of Southwestern Nigeria. Geological Application Indiogeologic, 20: 99-109.

Rahaman, M.A., 1989. Review of the basement geology of SW Nigeria: In Geology of Nigeria (Kogbe CA Ed.). Nigeria: Elizabeth Publishing Co. pp: 41-58. 